\title{
The Effectiveness of Stress Management Related to Employee's Efficiency-Chiaroscuro
}

\author{
Magdalene Peter, S.Fabiyola Kavitha, Banupriya.
}

\begin{abstract}
This module is intended to be used by educational employees who want to assist learners develop their capacity to deal with stress. It provides learners with information and usage strategies, but it also includes recommendations for incorporating components into the teaching of course content. For example, business learners exploring executives could examine stress management in terms of work stressors The purpose of this configuration is to help instructional staff provide a greater understanding and understanding of exertion to their learners. It also aims to include healthy habits to prevent discomfort and promote better university adjustment.
\end{abstract}

Keywords : chiaroscuro,stress management.

\section{INTRODUCTION}

Stress is a regular element of our lives. Some levels of stress are helpful, but really the amount of stress can still be prohibitive. Students at the university are undergoing many transitions. Studies has shown that universities can be a frustrating experience for learners, both Irish and international.[1-5]

Being able to manage and control stress is a useful capacity to live as a student, but also beyond college for life. On both a private and a professional basis management can be taught .The objects in this component can be used in relation to regular courses as a stand-alone course. It can also be incorporated into the track material, however, if necessary. Each section gives the presenter some location data about the region to be discussed, as well as recommendations for incorporating the content with the topic. If the teacher wants to present the material as a workshop, there is also a Proposed Summary. It includes suggested activities and procedures, necessary equipment and time estimate. The module also involves a slides and notes PowerPoint staging as well as exercises and handouts. The professor may be selective-using components or all module sections-or he / she may customize, modify, or add to the element[6-8]

\section{A.About stress}

"One of the issues with stress is that it can work for you or towards you, just like a vehicle tyre. You can drive smoothly along the road when the pressure in the tire is right: if it's too tiny, you feel all the bends and the systems feel bloated. To help students study more regarding the causes of stress and its implications. Early on, to help learners become aware of the signs and symptoms of pressure, to prevent chronic stress. To help students identify potential source of pressure and develop understanding that they can cope with pressure in

Revised Manuscript Received on July 22, 2019.

Magdalene Peter ,Department of Management studies,BharathInstitute of Higher Education and Research,Chennai,India.

S.FabiyolaKavitha,Department of Management studies,Bharath Institute of Higher Education and Research ,Chennai,India

Banupriya,Department of Management studies,Bharath Institute of Higher Education and Research, Chennai,India their living. To help students recognize their own perfect amount of stress.[9]

B. Definition Stress is a individual understanding that is normal and universal. Eustress or good stress, such as corporal activity or promotion, is stress that reimbursement our health. On the other hand, distress is stress that harms our health and often results from imbalances in meeting these demands between the demands imposed on us and our assets. The last is what mainly people think while they talk concerning pressure. However, if stress is well handled, it can increase inspiration and enhance us. [10]

There are many dissimilar description and stress hypothesis. conversely, the interactionist model of stress is a frequently recognized one (Lazarus \& Folkman, 1984). It indicates that three main elements are implicated

The state and requests Our objective assessment of the condition Our professed possessions to meet the requirements These requirements or condition might contain economic issues, urging, changes in the conditions of instruct / effort, etc. These are occurrences, annoy or modifications that may be physical or psychological in our external setting. They are sometimes called stressors. Situation evaluation refers to how we understand the situation or demand. For example, an event occurs. When Person B does not, it may be consider demanding by Person A. Thus, Person A is likely to respond either physiologically or emotionally to the stressful situation.[11-20]

Resources refer to our ability to cope with demand or stressor to cope with potential or real problems. Again, an incident happens, person A and person B both interpret it as difficult, but person A thinks it has the power to deal with it, But Person B thinks it's not, and they're going to react accordingly. While learners may not be able to handle some of the demands placed on them, they can change the tools at their disposal by improving their trying to cope strategies range.[21-24]

\section{II.OPTIMAL LEVEL OF STRESS}

Just have an optimal amount of stress, but it's distinct from individual to individual. Basically, if there is not anough stress, presentation may endure due to lack of incentive or monotony (see Figure 1). though, because of pressure-related issues such as failure to focus or disease, too much stress results in a fall in efficiency.

We need to know how to track Our stress levels, first of all to define our own optimum stress level and secondly to learn when we need to intervene to increase or decrease our stress level. This way stress works for us. By managing stress, we can improve our eminence of life and do a improved job, either in intellectual or capable life. 
If pressure is not treated correctly, it know how to improve an individual's adverse implications.[25-27]

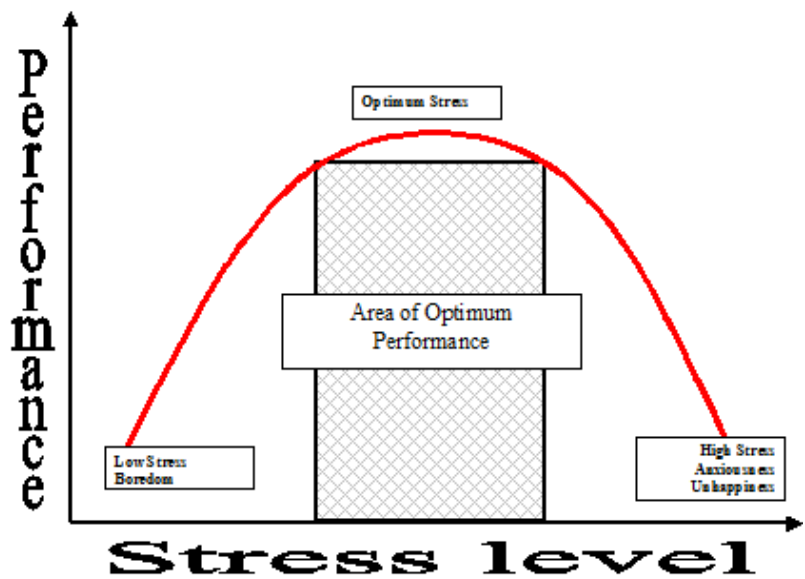

Fig.1 The relation ship between sress and management.

\begin{tabular}{|l|l|}
\hline Agree & $50 \%$ \\
\hline Partially agree & $30 \%$ \\
\hline Neutral & $10 \%$ \\
\hline Disagree & $2 \%$ \\
\hline
\end{tabular}

1. What kind of trouble do you feel in your work? (A) Group behavior (b) lack of data (c) Office politics and disputes (d) Excessive interruptions (a)Agreement (b) partial agreement (c) Neutral disagreement (d)

\section{III.SIGNS AND SYMPTOMS OF STRESS}

individuals will have their own private indications or responses to stress that they must learn to define. They usually fall into three classifications: physical, cognitive and emotional. Many of these symptom come and go as a consequence of small-phrase pressure yet symptoms connected with extended-phrase, continuing strain may be detrimental The impacts may include fatigue, bad morals, and ill health. High stress levels without interference or leadership can lead to mental health issues (e.g. depression, anxiety, interpersonal issues), behavioral modifications (e.g. enhanced alcohol intake, drug abuse, appetite disorders) and on occasion health implications. (e.g. headaches, intestinal problems, heart disease, etc.).[28-29]

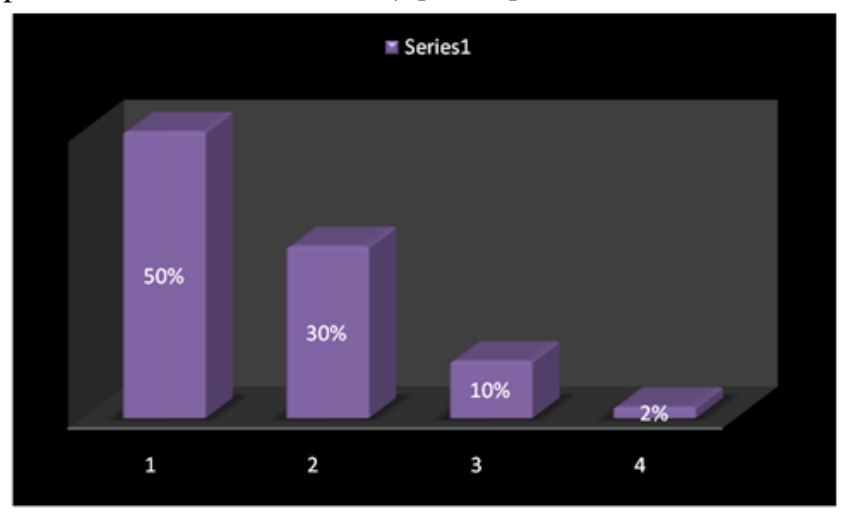

Fig 2

Interpretation:

Approximately 50 percent of staff agree that task setting offers goals in assessing their trouble if you feel in your work that 30 percent of staff are partly satisfied with the declaration and 10 percent are neutral and 2 percent disagree and do not fill out the questionnaire. 50\% 30\% $10 \%$

\begin{tabular}{|l|l|}
\hline Agree & $50 \%$ \\
\hline Partially agree & $30 \%$ \\
\hline Neutral & $10 \%$ \\
\hline Disagree & $2 \%$ \\
\hline No comments & $0 \%$ \\
\hline
\end{tabular}

2 When you're forced to work overtime, how do you cope with it? A) Reduce my efforts b) Slowly make efforts c) Annoy myself with job d) Do not make any additional attempts e) Complain on it (a)Agree (b) partly agree (c) Neutral (d) disagree (e) No remarks

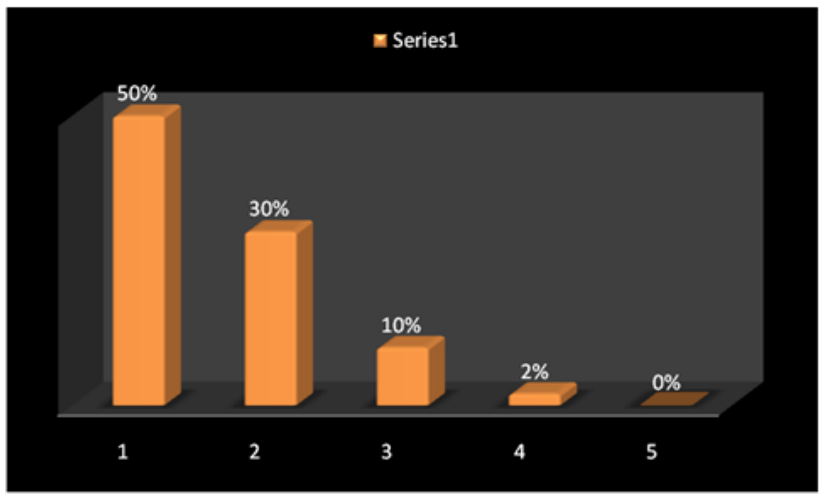

Fig.3

Interpretation:

Approximately 50 percent of staff agree that task setting offers goals in assessing their compulsory job overtime, than 30 percent of staff are partly satisfied with the declaration and 10 percent are neutral and 2 percent disagree and do not fill out the questionnaire. 50\% 30\% 10\% 2\% 0\% Task Setting Agreement Partially Agree Neutral Disagree with no remarks 3. Under what circumstances do you get assistance from the individuals above? (A) All fresh duties b) Early phase of all assignments c) Work-related problems d) Home-related problems e)

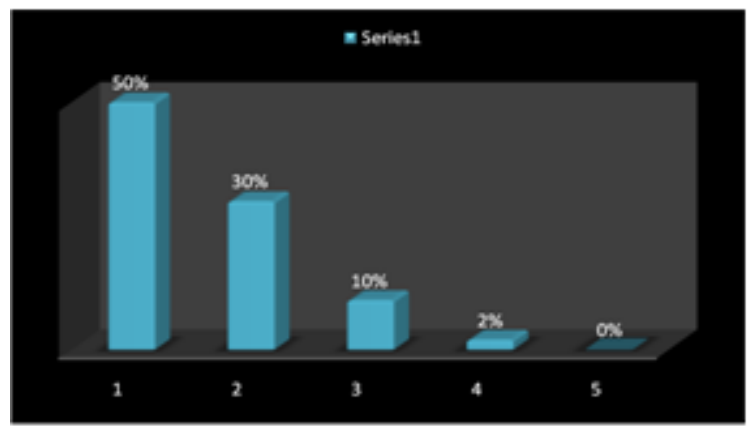

Fig.4

Interpretation:

About $50 \%$ of employees agree that task Setting provides objectives in appraising their get support from above people than $30 \%$ of the employees are partially agreed with the statement and $10 \%$ are neutral \& $2 \%$ are disagreed and not fill the questionnaire. 50\%30\% 10\% 2\% 0\% Task setting Agree Partiallyagree Neutral Disagree no comments[33]

4. Does stress show its impact on your health?

a) Yes b) No 


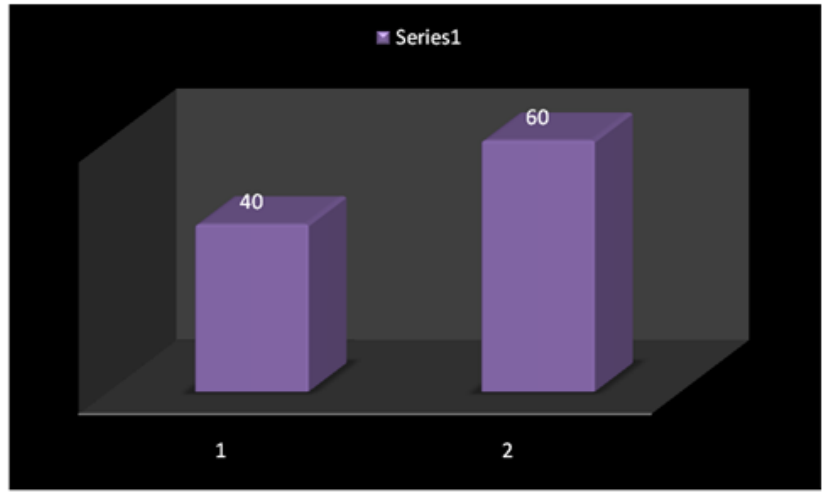

Fig.5

\begin{tabular}{|l|l|}
\hline yes & $40 \%$ \\
\hline no & $60 \%$ \\
\hline
\end{tabular}

Interpretation:

About $40 \%$ of employees agree that impact on your health $60 \%$ of the employees are not having health issues

5.What makes you feel overloaded at job? A) Lack of funds needed b) Lack of employees c) More administration and paperwork d) Continuous and messy job demands e) Lack of work assistance[30]

\begin{tabular}{|l|l|}
\hline Shortages of resources required & $40 \%$ \\
\hline Inadequate employees & $30 \%$ \\
\hline More paper and administration operate & $10 \%$ \\
\hline Continuous and messy work requirements & $20 \%$ \\
\hline Help shortages at job & $0 \%$ \\
\hline
\end{tabular}

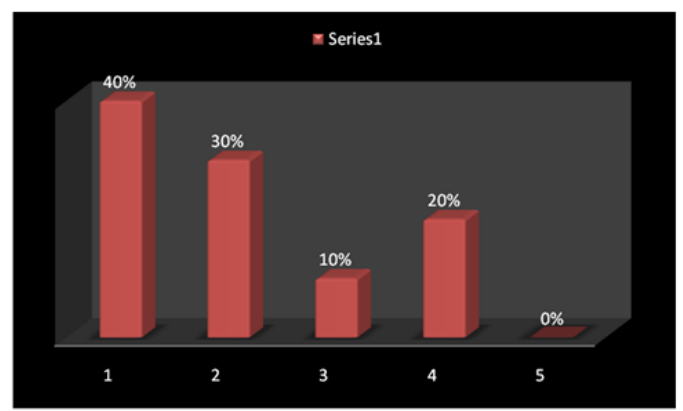

Fig.6

\section{Interpretation:}

About $40 \%$ of employees Shortage of required resources $30 \%$ of the Employees Insufficient co-workers More administration and paper work 10 percent Continuous and messy job requirements 20 percent shortage of work assistance 0 percent 6 . Have you used the stress management equipment provided by your workplace? [32]

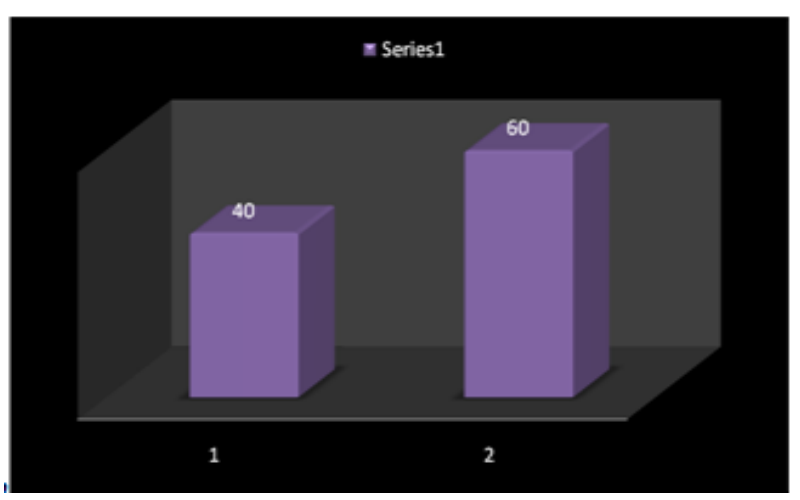

Fig.7
A)yes b) no

\begin{tabular}{|l|l|}
\hline yes & $40 \%$ \\
\hline no & $60 \%$ \\
\hline
\end{tabular}

Interpretation:

About $40 \%$ of employees agree that Stress management services provided by your workplace 60 percent of staff do not have the stress management services provided by your workplace 7. To what extent do you overcome stress by using stress management equipment and coping strategies?

A) To a large extent b) To a certain extent c) No change

\begin{tabular}{|l|l|}
\hline To a immense level & $40 \%$ \\
\hline To a few point & $40 \%$ \\
\hline No transform & $20 \%$ \\
\hline
\end{tabular}

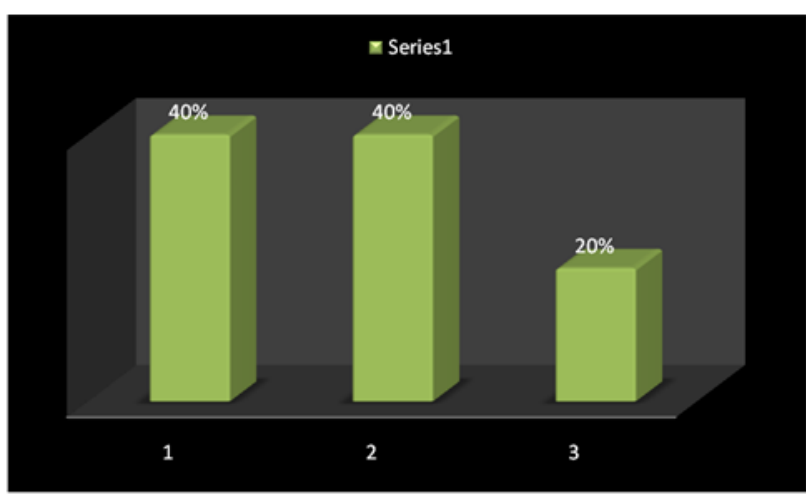

Fig.8

\section{IV.CONCLUSION}

About 40 percent of staff agree that overcoming stress by using stress management equipment 40 percent of staff do not overcome stress by using stress management equipment 20 percent of staff do not change stress by using stress management equipment.

\section{REFERENCES}

1) BharthVajan R., Ramachandran S.,Psychographic dimensions of training,2016,International Journal of Pharmacy and Technology,V-8,I-4,P-23727-23729

2) Balakrishnan P., Bharthvajan R.,A study on human resource planning in hospitals in Chennai City,2014,International Journal of Applied Engineering Research,V-9,I-22,P-7503-7507

3) Priyadarsini P., Bharthvajan R.,Role of emotional intelligence training programme in reducing the stress of the nurses,2014,International Journal of Applied Engineering Research,V-9,I-22,P-7411-7421

4) Kerinab Beenu G., Bharthvajan R.,Empirical analysis on the cosmetic buying behavior of young women in South India,2014,International Journal of Applied Engineering Research,V-9,I-22,P-7361-7366

5) Balakrishnan P., Bharthvajan R.,Whistling in the wind,2014,International Journal of Applied Engineering Research,V-9,I-22,P-7586-7593

6) Krishnan B., Peter M.,Health hazards of Indian Bpo employee-an alarming issue,2014,International Journal of Applied Engineering Research,V-9,I-22,P-7336-7341

7) Kerinab Beenu G.H., Peter M.,Role of insurance in economic development,2014,International Journal of Applied Engineering Research,V-9,I-22,P-7532-7539

8) Balakrishnan P., Peter M., Priyadarsini P.,Efficiency of safety measures for wellbeing of employees in manufacturing industry,2014,International Journal of Applied Engineering Research,V-9,I-22,P-7376-7382

9) Anbarasi M., Praveen Kumar S.,Online sales promotions of herbal products and its effectiveness towards tanisha.com,2019,Indian Journal of Public Health Research and Development,V-10,I-1,P-195-200 
10) Anbarasi M., Praveen Kumar S.,Various online marketing and promotions strategies to improve the validation towards the organic products in the pharmaceutical sectors,2019,Indian Journal of Public Health Research and Development,V-10,I-1,P-263-269

11) Loganathan R., Praveen Kumar S.,Grievance handling a key factor for solving issues of employees in an organization,2014,International Journal of Applied Engineering Research,V-9,I-22,P-7483-7491

12) Loganathan R., Praveen Kumar S.,Study on preference of private label brands in super and Hypermarkets,2014,International Journal of Applied Engineering Research,V-9,I-22,P-7327-7335

13) Smitha M., Praveen Kumar S.,Understanding stress and its managementamong the nurses in Chennai city,2014,International Journal of Applied Engineering Research,V-9,I-22,P-7560-7565

14) Kerinab Beenu G.H., Praveen Kumar S.,A study on the investment behavior of Chennai investors in mutual fund schemes,2014,International Journal of Applied Engineering Research,V-9,I-22,P-7520-7525

15) Loganathan R., Praveen Kumar S.,Retention strategies key for organizational productivity,2014,International Journal of Applied Engineering Research,V-9,I-22,P-7443-7447

16) Pavithra J., Ganesan M., Brindha G.,State wise analysis of microfinance sector in India,2016, International Journal of Pharmacy and Technology,V-8,I-4,P-23417-23432

17) Pavithra J., Ganesan M.,A comparative study on microfinance in India and abroad,2016,International Journal of Applied Business and Economic Research,V-14,I-8,P-5471-5476

18) Pavithra J., Ganesan M.,A study on awareness and impact of micro-financial schemes,2016,International Journal of Applied Business and Economic Research,V-14,I-8,P-5449-5460

19) Senthilmurugan P., Pavithra J.,Consumer preference towards organised retailing with reference to Big Bazaar,2014,International Journal of Applied Engineering Research,V-9,I-22,P-7469-7475

20) Senthilmurugan P., Pavithra J.,Implication of social media marketing in growing healthcare industry,2014,International Journal of Applied Engineering Research,V-9,I-22,P-7448-7456

21) Loganathan R., Pavithra J.,Consumer perception towards private label brand over other brands in super markets and hypermarkets,2014,International Journal of Applied Engineering Research,V-9,I-22,P-7355-7360

22) Kerinab Beenu G., Pavithra J.,Tradeâ€"off between liquidity and profitability in logistics industry,2014,International Journal of Applied Engineering Research,V-9,I-22,P-7398-7401

23) Kerinab Beenu G., Pavithra J.,A study on the prospective consumerâ $€^{\mathrm{TM}_{\mathrm{S}}}$ perception towards utility cars in Chennai city,2014,International Journal of Applied Engineering Research,V-9,I-22,P-7526-7531

24) Pavithra J., Dilli Babu P., Ambuli T.V.,A study on budgetary control at Maruti Service Masters, Chennai,2014,International Journal of Applied Business and Economic Research,V-12,I-2,P-151-161

25) Pavithra J., Dilli Babu P., Ambuli T.V.,A study on customer satisfaction of retro Garments Pvt Ltd, Chennai,2014,International Journal of Applied Business and Economic Research,V-12,I-2,P-381-391

26) Kerinab Beenu G.H., Pavithra J., Senthilmurugan P.,A study on the influence of promotional activities for TATA ARIA among consumers in Chennai,2014,International Journal of Applied Engineering Research,V-9,I-22,P-7572-7578

27) Vijayaragavan S.P.,An investigative expert that's general FBG sensors,International Journal of Mechanical Engineering and Technology,V-8,I-8,PP-1500-1505,Y-2017

28) Vijayaragavan S.P.,Equalization routing protocol for $\mathrm{Wi}-\mathrm{Fi}$ sensor strategy,International Journal of Mechanical Engineering and Technology,V-8,I-8,PP-1662-1666,Y-2017

29) Karthik B., Kiran Kumar T.V.U., Vijayaragavan P., Bharath Kumaran E.,Design of a digital PLL using 0.35 $\hat{\mathrm{I}}^{1 / 4 \mathrm{~m}}$ CMOS technology,Middle East Journal of Scientific Research,V-18,I-12,PP-1803-1806,Y-2013

30) Kanniga E., Selvaramarathnam K., Sundararajan M.,Kandigital bike operating system,Middle - East Journal of Scientific Research,V

31) Jasmin M., Vigneshwaran T., Beulah Hemalatha S.,Design of power aware on chip embedded memory based FSM encoding in FPGA,International Journal of Applied Engineering Research,V-10,I-2,PP-4487-4496,Y-2015

32) Jasmin M.,Optimization techniques for low power VLSI circuits,Middle - East Journal of Scientific Research,V-20,I-9,PP-1082-1087,Y-2014

33) Jasmin M., Vigneswaran T.,Fuzzy controller for error control of on Chip communication,2017 International Conference on Algorithms,
Methodology, Models and Applications in Emerging Technologies, ICAMMAET 2017,V-2017-January,I-,PP-1-5,Y-2017

\section{AUTHORS PROFILE}

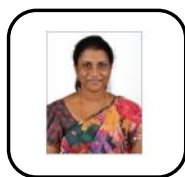

Magdalene Peter Assistant Professor,

Department of Management studies,BharathInstitute of Higher Education and Research,Chennai,India

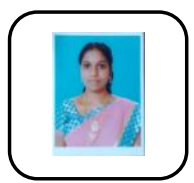

S.Fabiyola Kavitha Associate Professor.

Department of Management studies,BharathInstitute of Higher Education and Research,Chennai,India.

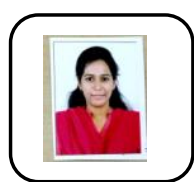

Banupriya Student,. Department of Managemen studies,BharathInstitute of Higher Education and Research,Chennai,India 